\title{
SEDIAAN VAKSIN Mycobacterium fortuitum ISOLAT LOKAL YANG EFEKTIF UNTUK PENCEGAHAN PENYAKIT Mycobacteriosis PADA IKAN GURAMI, Osphronemus gouramy
}

\author{
Uni Purwaningsih $^{\#}$, Taukhid, Angela Mariana Lusiastuti, Desy Sugiani, dan Tuti Sumiati \\ Balai Penelitian dan Pengembangan Budidaya Air Tawar
}

(Naskah diterima: 9 Februari 2015; Revisi final: 11 Agustus 2015, Disetujui publikasi: 2 September 2015)

\begin{abstract}
ABSTRAK
Mycobacteriosis merupakan penyakit yang bersifat kronis progresif yang rentan menyerang ikan gurami, dengan tingkat prevalensi mencapai 30\%-80\%. Berbagai upaya telah dilakukan untuk mencegah dan mengendalikan penyakit tersebut dengan menggunakan antibiotik, bahan kimia maupun terapi herbal namun belum memberikan hasil yang optimal. Vaksinasi diharapkan mampu menjadi solusi alternatif dan aplikatif untuk pencegahan penyakit Mycobacteriosis pada ikan gurami. Penelitian ini bertujuan untuk memperoleh jenis sediaan vaksin M. fortuitum yang tepat untuk mencegah penyakit Mycobacteriosis pada ikan gurami. Isolat $M$. fortuitum kode 31 digunakan sebagai isolat kandidat vaksin. Inaktifasi vaksin dilakukan dengan sonikasi dan neutral buffer formalin 3\%. SDS PAGE terhadap sediaan sel utuh dan broth menunjukkan jumlah pita protein yang lebih variatif. Berdasarkan uji innocuity dan uji sterility terhadap berbagai sediaan vaksin menunjukkan bahwa vaksin terbukti aman dan tidak menyebabkan efek samping pada ikan gurami. Peningkatan titer antibodi terjadi 14 hari pasca vaksinasi. Titer antibodi pada perlakuan vaksin menunjukkan perbedaan yang nyata $(\mathrm{P}<0,05)$ dibanding kontrol pasca uji tantang. Kematian ikan pasca uji tantang dengan menggunakan bakteri $M$. fortuitum $10^{6} \mathrm{cfu} / \mathrm{mL}$ menunjukkan pola kematian yang bersifat kronis. Kematian mulai terjadi setelah hari ke-19 pasca uji tantang. Ikan gurami yang divaksinasi dengan vaksin sel utuh M. fortuitum menunjukkan hasil terbaik dengan tingkat sintasan sebesar 83,33\% dan relative percent survival (RPS) sebesar 66,67\%.
\end{abstract}

KATA KUNCI: $\quad$ vaksin, Mycobacterium fortuitum, gurami (Osphronemus gouramy)

ABSTRACT: The effective vaccine of Mycobacterium fortuitum from local isolate to prevent Mycobacteriosis diseases in gurami (Osphronemus gouramy). By: Uni Purwaningsih, Taukhid, Angela Mariana Lusiastuti, Desy Sugiani, and Tuti Sumiati

\begin{abstract}
Mycobacteriosis is a chronic progressive disease which infected gouramy. The prevalence of Mycobacteriosis was reach $30 \%-80 \%$. The efforts to prevent and control this disease were done by using antibiotics, chemicals and herbal therapy were not effective. Vaccination is expected to be an alternative solution for prevention from Mycobacteriosis and applicable in gouramy. The aim of this study was to evaluate the effectivity of local isolate M. fortuitum vaccine to prevent Mycobacteriosis in gouramy. Isolate M. fortuitum code 31 was used as the vaccine candidate. Inactivated vaccine was performed by sonication and 3\% neutral buffered formalin. The SDS PAGE analysis of the whole cell and broth preparations were indicate the number of protein bands more than two other types vaccine else. Based on the innocuity test and sterility test from the various vaccine preparations in gouramy showed that the vaccine was safe and did not cause negative effects in gouramy. The titre of antibody increased after 14 days postvaccination. The antibody titre of the vaccinated fish showed higher significantly different $(P<0.05)$, compared to control. The fish mortality after challenge test using $M$. fortuitum $10^{6} \mathrm{cfu}$ showed chronic infection in gouramy. The mortality after challenge test was began after 19 day post challenge. The vaccinated fish with whole cell vaccines M. fortuitum showed the best results with a survival rate of $83.33 \%$ and relative percent survival (RPS) of $66.67 \%$.
\end{abstract}

KEYWORDS: vaccine, Mycobacterium fortuitum, gouramy (Osphronemus gouramy)

\# Korespondensi: Balai Penelitian dan Pengembangan Budidaya Air Tawar. Jl. Raya Sempur No. 1, Bogor 16154 , Indonesia. Tel.: + (0251) 8313200

E-mail: uni_fish@yahoo.com; lusiastuti_61@yahoo.co.id; 


\section{PENDAHULUAN}

Gurami merupakan salah satu komoditas unggulan pada budidaya ikan air tawar, yang berkembang cukup pesat. Satu di antara masalah yang menghambat dalam budidaya ikan gurami adalah faktor penyakit. Penyakit yang rentan menyerang gurami disebabkan oleh bakteri Mycobacterium fortuitum yang dikenal sebagai Mycobacteriosis atau Fish Tubercullosis.

M. fortuitum merupakan bakteri patogen yang dapat menyerang jenis ikan air tawar maupun laut. Tingkat infeksi dalam suatu populasi dapat bervariasi dari 10\% hingga 100\% (Irianto, 2005). Menurut Rukmono (2010), penyakit Mycobacteriosis memiliki tingkat prevalensi sebesar $20 \%-80 \%$ dari total populasi pada budidaya ikan gurami. Mycobacteriosis merupakan jenis penyakit kronis yang progresif. Butuh waktu lama untuk menunjukkan gejala klinis antara lain: ikan lemah, pembengkakan pada kulit, mata menonjol (exopthalmia), lesi, dan borok pada tubuh (Purwaningsih et al., 2009). Kasus kematian akibat infeksi bakteri $M$. fortuitum menjadi penghambat keberhasilan produksi budidaya ikan gurami. Penyakit tersebut mengakibatkan kerugian ekonomi dan menurunkan kualitas produk ikan gurami yang dihasilkan.

M. fortuitum sering resisten terhadap antibiotik tetapi diduga peka terhadap amikasin, doksisiklin, sefoksitin, eritromisin, atau rimfasin walaupun pada realisasi pengobatannya memberikan hasil yang bervariasi dan kurang maksimal (Jawetz et al., 1996). Berdasarkan data penelitian di India, kejadian tuberkolosis terhadap manusia sudah menunjukkan resistensi terhadap isoniazid, rifampicin, inhethionamide, streptomisin, fluoroquinolone, pyrazinamide, dan ethambutol. Oleh karena itu, perlu dicari solusi aplikatif untuk penyakit tersebut melalui pembekalan imun spesifik dengan pemberian vaksin M. fortuitum yang diharapkan dapat mencegah timbulnya infeksi penyakit tersebut pada budidaya gurami.

Vaksinasi merupakan upaya untuk meningkatkan respons imun terhadap patogen tertentu yang berdasarkan pada dua elemen imunitas adaptif yaitu spesifitas dan memori. Pencegahan penyakit Mycobacteriosis akibat infeksi $M$. fortuitum dengan metode vaksinasi belum menunjukkan hasil yang optimal. Beberapa kajian mengenai penelitian vaksin $M$. fortuitum yang telah dilakukan menunjukkan hasil yang bervariasi. Bangkit (2011) menyatakan vaksin sediaan broth dengan dosis $10^{7} \mathrm{cfu}$ mampu menginduksi respons kekebalan spesifik ikan gurami dengan nilai sintasan relatif $80 \%$ dan tingkat gejala klinis ringan setelah diuji tantang. Vaksin M. fortuitum sediaan Produk Ekstraselular (ECP) dengan dosis rendam $10^{9} \mathrm{cfu}$ memberikan pengaruh dalam merangsang sistem imun ikan gurami dengan nilai sintasan relatif sebesar $80,02 \%$. Begitu juga yang dilaporkan oleh Chen et al. (1997) bahwa produk ekstrasellular Mycobacterium sp. mengandung protein 14-65 kDa yang bersifat toksik terhadap ikan rainbow trout dan nila yang diinjeksikan ECP sebanyak $400 \mu \mathrm{g}$ secara intramuskular. Pada penelitian yang dilakukan oleh Chen et al. (1997) menyatakan bahwa ikan nila yang divaksinasi dengan produk ECP menunjukkan peningkatan jumlah nitroblue tetrazolium (NBT) dan aktivitas lisosim pada hari ke-4 pasca vaksinasi.

Penelitian ini merupakan upaya untuk mengeksplorasi jenis sediaan vaksin $M$. fortuitum yang efektif dan berpotensi sebagai antigen dan bahan vaksin dalam menginduksi respons kekebalan spesifik pada ikan gurami untuk mencegah penyakit Mycobacteriosis.

\section{BAHAN DAN METODE}

\section{Preparasi Sediaan Vaksin M. fortuitum}

Preparasi sediaan vaksin menggunakan isolat $M$. fortuitum kode 31. Satu koloni bakteri $M$. fortuitum dikultur ke dalam $100 \mathrm{~mL}$ Sauton Broth dengan inkubasi selama $72 \mathrm{jam}$ pada suhu $37^{\circ} \mathrm{C}$. Inaktifasi dilakukan dengan sonikasi sebanyak tiga kali dengan waktu empat menit dan interval satu menit dan dilanjutkan dengan menggunakan neutral buffer formalin 3\% selama empat jam. Proses yang demikian menghasilkan sediaan vaksin broth. Sedangkan untuk sediaan vaksin sel utuh dan extracelluler product (ECP) dilanjutkan dengan mensentrifus sebanyak $100 \mathrm{~mL}$ plasebo dengan kecepatan $3.000 \mathrm{~g}$ selama 30 menit. Pelet yang diperoleh disuspensi ke dalam $\mathrm{NaCl} 0,845 \%$ dengan perbandingan $1: 10(\mathrm{v} / \mathrm{v})$ untuk memperoleh vaksin sel utuh. Sedangkan supernatan yang diperoleh dijadikan sediaan vaksin ECP. Sediaan vaksin ECP dengan filtrasi diperoleh dengan melakukan penyaringan supernatan menggunakan microfilter syringe yang berukuran $0,22 \mu \mathrm{m}$.

\section{Uji Keamanan Vaksin (Innocuity Test)}

Uji keamanan vaksin dilakukan dengan menginjeksi sediaan vaksin pada ikan gurami (Osphronemus gouramy) secara intra peritoneal (IP) dan sebagai kontrol ikan diinjeksi dengan larutan fisiologis berdasarkan metode Anderson et al. (1970). Setelah 28 hari dilakukan reisolasi bakteri $M$. fortuitum dari organ hati, ginjal dan mata ikan perlakuan. Vaksin dikatakan aman jika hasil dari reisolasi tidak diperoleh bakteri aktif yang sama dengan isolat vaksin.

\section{Uji Sterilitas Vaksin (Sterility Test)}

Uji sterilisasi dilakukan dengan melakukan kultivasi sediaan vaksin dalam Soyton agar yang diinkuba- 
si pada suhu $37^{\circ} \mathrm{C}$ selama 72 jam untuk memastikan tidak ada bakteri yang tumbuh dari jenis M. fortuitum yang sama seperti bakterin sediaan vaksin.

Analisis Protein Sel Utuh menggunakan Sodium Dodecyl Sulphate-Polyacrylamide Gel Electrophoresis (SDS-PAGE)

Preparasi sediaan lysate sel utuh dari M. fortuitum diisolasi menggunakan metode pemurnian Encheva et al. (2006). Sebanyak $200 \mathrm{mg}$ (berat basah) sel diresuspensi dalam $1 \mathrm{~mL}$ lysis buffer $(0,2 \%$ SDS, $133 \mathrm{~mm}$ DTT, $17 \mathrm{~mm} \mathrm{MgCl}$, $50 \mathrm{~mm}$ Tris) yang berisi $375 \mathrm{U}$ benzonase (Sigma) dan $350 \mathrm{U}$ mutanolysin (Sigma). Sel diinkubasi 24 jam pada $37^{\circ} \mathrm{C}$ kemudian dipindahkan ke dalam Lysing Matrix B tubes (MP Biomedicals) dan dihomogenkan selama 30 menit dalam FastPrep24 (MP Biomedicals) dengan pendinginan setiap dua menit di atas es.

Sel utuh disentrifus pada $16.000 \mathrm{~g}$ selama 30 menit pada suhu $4^{\circ} \mathrm{C}$, dan supernatan dikumpulkan kemudian disimpan pada suhu $-80^{\circ} \mathrm{C}$. Setiap isolat, berisi protein dalam $100 \mu \mathrm{L}$ aliquot dipresipitasi menggunakan trichloroacetic acid/acetone dan diresuspensi pada volume yang sama dengan PBS, untuk menguji sterilitas dari protein dilakukan protein assays, yaitu konsentrasi protein diuji menggunakan Micro BCA-Protein Assay (Pierce).

Whole-cell lysates dari setiap isolat dianalisis dengan SDS-PAGE (LaFrentz et al., 2004). Protein (25 $\mu \mathrm{g})$ dipisahkan dalam $12 \%$ polyacrylamide gel menggunakan Mini-Protein Tetra Cell (Bio-Rad) dan kemudian diwarnai dengan Bio-Safe Coomassie (Bio-Rad). Precision Plus protein standards (Bio-Rad) digunakan untuk menghitung massa molekul dari band protein. Gel kemudian difoto menggunakan densitometer (BioRad).

\section{Vaksinasi pada Gurami Uji}

Ikan gurami (0. gouramy) uji yang digunakan berukuran 25-35 g. Ikan yang digunakan harus memenuhi asumsi Specific Pathogen Free (SPF) melalui pemeriksaan secara bakteriologis dan PCR dari organ target penyakit Mycobacteriosis. Vaksinasi dilakukan secara injeksi intraperitoneal dengan volume $0,1 \mathrm{~mL}$. Rancangan penelitian menggunakan rancangan acak lengkap (RAL) dengan lima perlakuan dan tiga ulangan. Perlakuan meliputi jenis vaksin yang digunakan: (A) vaksin ECP dengan filtrasi, (B) vaksin ECP, (C) vaksin sel utuh, (D) vaksin broth dan (D) kontrol.

Masa induksi kekebalan diamati selama 21 hari. Parameter pengamatan dilakukan terhadap kematian harian, titer antibodi (Anderson \& Siwicki, 1995), diferensial leukosit (Anderson \& Siwicki, 1995) dan aktifitas fagositosis (Zhang et al., 2008).

\section{Uji Tantang}

Uji tantang dilakukan 21 hari setelah masa induksi kekebalan dengan menggunakan bakteri $M$. fortuitum $10^{6} \mathrm{cfu} / \mathrm{mL}$ selama 28 hari pengamatan. Wadah uji tantang berupa akuarium volume $80 \mathrm{~L}$. Ikan yang digunakan untuk uji tantang masing-masing perlakuan sebanyak 60 ekor dan dibagi dalam tiga ulangan. Pengambilan sampel dilakukan sebelum dan sesudah uji tantang, terhadap parameter uji dilakukan sebelum perlakuan. Indikator keberhasilan vaksinasi dilakukan pengukuran terhadap titer antibodi (Anderson \& Siwicki, 1995), diferensial leukosit (Anderson \& Siwicki, 1995), aktifitas fagositosis (Zhang et al., 2008), tingkat sintasan dan relative percent survival (RPS) (Ellis, 1988).

\section{HASIL DAN BAHASAN}

Uji innocuity terhadap berbagai sediaan vaksin $M$. fortuitum menunjukkan tidak terjadi kematian setelah 24 jam pasca vaksinasi. Perubahan secara fisiologis dan anatomis juga tidak ditemukan. Reisolasi terhadap gurami uji dari masing-masing kelompok perlakuan menunjukkan tidak diperoleh adanya pertumbuhan bakteri pada media kultur. Kematian setelah 24 jam pascavaksinasi tidak terjadi, perubahan fisiologis dan anatomis pada gurami uji tidak ditemukan. Hal ini menandakan bahwa sediaan vaksin yang diberikan terbukti aman dan tidak menimbulkan efek samping. Penggunaan Neutral buffer formalin sebagai bahan inaktifasi bakteri memberikan tingkat keamanan yang sangat baik dibanding jika menggunakan formalin yang seringkali menimbulkan perubahan pada tingkah laku dan ditemukannya peradangan pada area bekas suntikan. Hal tersebut disebabkan oleh efek toksik dari formalin yang berpengaruh secara fisiologis dan anatomis pada ikan.

Hasil uji sterility terhadap masing-masing sediaan vaksin $M$. fortuitum tidak ditemukan adanya pertumbuhan bakteri pada media kultur, hal tersebut menunjukkan bahwa proses inaktifasi efektif dan tidak ada kontaminasi mikroba selama proses pembuatan vaksin.

Profil protein sediaan vaksin $M$. fortuitum sediaan ECP dengan fitrasi terdiri atas tiga pita protein, sedangkan sediaan ECP (12 pita protein), sel utuh dan broth masing-masing terdiri atas 17 pita protein, hal tersebut ditunjukkan pada Gambar 1.

Berdasarkan hasil analisis SDS Page menunjukkan bahwa sediaan vaksin sel utuh dan broth memiliki jumlah pita protein yang lebih banyak dari sediaan lainnya yaitu 17 pita protein, dapat dilihat pada Tabel 1. Protein yang mendekati $65 \mathrm{kDa}$ juga ditemukan pada vaksin $M$. fortuitum sediaan sel utuh dan 


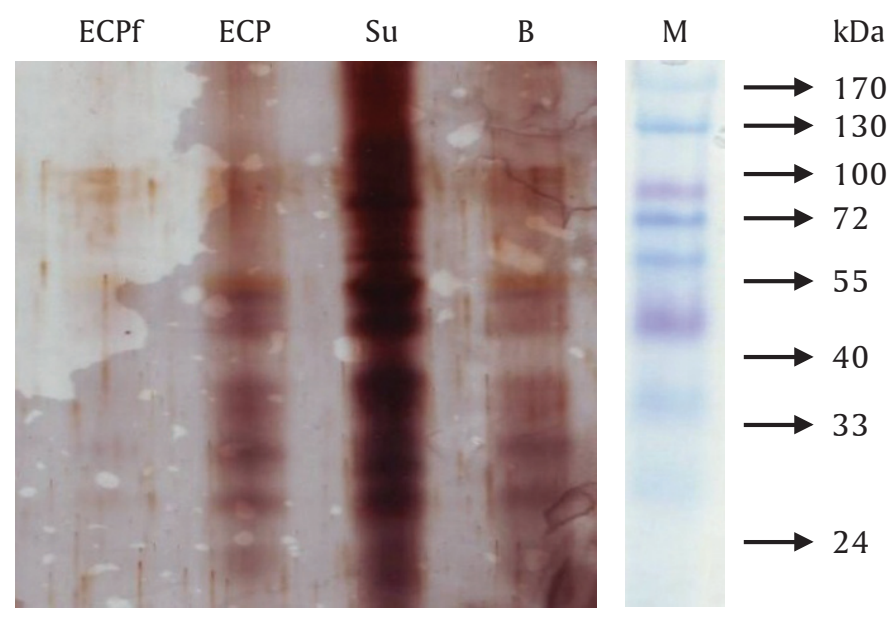

Gambar 1. SDS-PAGE berbagai sediaan vaksin bakteri Mycobacterium fortuitum. $\mathrm{M}=$ Marker; ECPf = Vaksin sediaan ECP filter; ECP = Vaksin sediaan ECP; Su = Vaksin sediaan sel utuh; B = Vaksin sediaan broth

Figure 1. SDS-PAGE of many kinds Mycobacterium fortuitum vaccine. $M=$ Marker; ECPf $=E C P$ vaccine with filtration; $E C P=E C P$ vaccine $; S u=$ Whole cell vaccine; $B=$ Broth vaccine

Tabel 1. Karakteristik berat molekul protein dari berbagai sediaan vaksin M. fortuitum

Table 1. Characteristic of molecular weight proteins from different vaccine preparations of M. fortuitum

\begin{tabular}{lc}
\hline $\begin{array}{c}\text { Sediaan vaksin } \text { M. fortuitum } \\
\text { Vaccine preparations of } M \text {. fortuitum }\end{array}$ & $\begin{array}{c}\text { Berat molekul } \\
\text { Molecular weight (kDa) }\end{array}$ \\
\hline Vaksin ECPf (ECP with filtration vaccine) & $133,121,75$ \\
Vaksin ECP (ECP vaccine) & $133,127,121,75,66,59,44,40,32,25$, \\
Vaksin sel utuh (Whole cell vaccine) & 17,7 \\
Vaksin broth (Broth vaccine) & $133,121,115,102,95,88,77,70,64,47$, \\
& $42,31,26,19,17,13,8$ \\
& $133,121,115,102,95,88,77,70,64,47$, \\
\end{tabular}

broth yaitu $64 \mathrm{kDa}$ dan pada sediaan ECP yaitu 66 $\mathrm{kDa}$, yang merupakan protein yang bersifat imunogenik. Chen et al. (1997) mengemukakan bahwa profil protein ECP Mycobacterium spp. pada ikan menunjukkan pita utama pada $65 \mathrm{kDa}$ dan $<14 \mathrm{kDa}$ sedangkan pita lain yang teridentifikasi juga berukuran $70,45,40,38$, dan $25 \mathrm{kDa}$. Sel utuh sonikasi menunjukkan pita utama pada ukuran $68,65,55,50$, 31 , 27, dan $16 \mathrm{kDa}$ serta pita yang berukuran $>97$ kDa. Antigen berbagai sediaan vaksin M. fortuitum mengandung material protein yang bersifat imunogenik dengan ukuran 60-133 kDa, ini sesuai dengan pernyataan Stuart (1999) bahwa molekul antigen yang bersifat imunogenik memiliki ukuran lebih besar dari $60 \mathrm{kDa}$.

Keberhasilan vaksinasi dapat diukur dari beberapa parameter respons imun spesifik dan non spesifik untuk mengetahui keamanan dan level proteksi aplikasi vaksin pada ikan. Pada penelitian ini dilakukan pengamatan terhadap parameter titer antibodi, diferensial leukosit, dan aktivitas fagositosis.

Titer antibodi ikan gurami dengan perlakuan berbagai sediaan vaksin M. fortuitum (Gambar 2) menunjukkan perbedaan yang nyata dibanding dengan kontrol $(\mathrm{P}<0,05)$. Hasil pengamatan antar perlakuan vaksin diperoleh hasil yang menunjukkan bahwa perlakuan vaksin jenis sediaan sel utuh memiliki titer antibodi yang lebih tinggi, setelah diuji tantang dengan bakteri M. fortuitum pada nilai $7(\log 2)$.

Pemberian berbagai sediaan vaksin $M$. fortuitum terbukti mampu menginduksi respons imun spesifik pada ikan gurami. Peningkatan titer antibodi terjadi setelah dua minggu atau 14 hari pascavaksinasi dan secara signifikan meningkat pada minggu ke-3 pascavaksinasi. Penurunan titer antibodi terjadi satu minggu setelah uji tantang dan meningkat kembali dua minggu setelah uji tantang. 


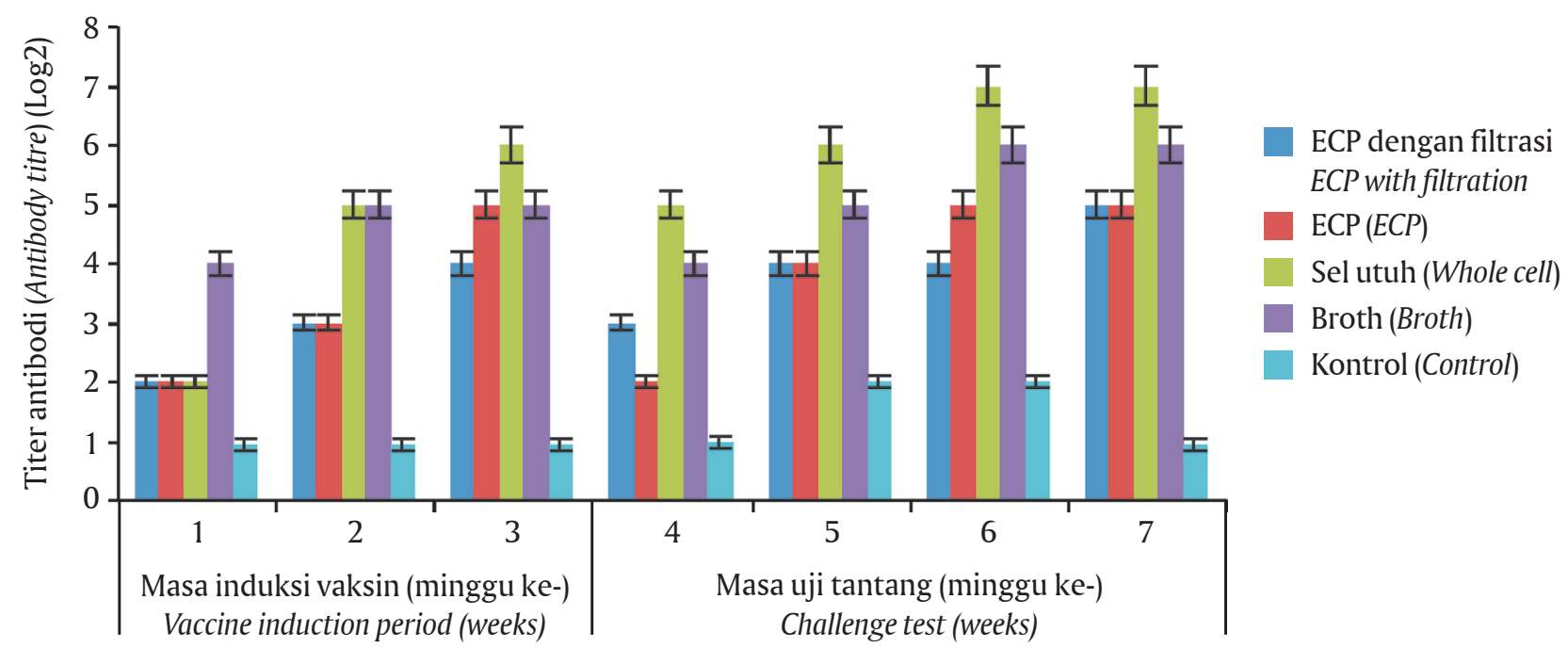

Gambar 2. Titer antibodi serum ikan gurami (0. gouramy) pascavaksinasi dan pasca uji tantang dengan bakteri M. fortuitum

Figure 2. $\quad$ Antibody titre of gouramy (O. gouramy) serum post vaccination and post challenge test with bacteria M. fortuitum

Penurunan titer antibodi yang terjadi satu minggu setelah uji tantang dengan bakteri M. fortuitum, merupakan respons fisiologis normal di mana tubuh ikan akan memberikan respons terhadap adanya patogen atau benda asing yang menginfeksi. Antibodi bereaksi spesifik dengan antigen membentuk senyawa kompleks berupa endapan (presipitat) dan gumpalan (aglutinat) yang ditujukan melalui uji imunopresipitasi atau uji aglutinasi. Titer antibodi mencerminkan kemampuan tubuh ikan terhadap infeksi bakteri melalui respons imun spesifik. Semakin tinggi nilai titer maka diharapkan kemampuan perlindungan terhadap infeksi juga menjadi tinggi. Antibodi yang beredar dalam darah akan menetralisasi molekul antifagositik dan eksotoksin lainnya yang diproduksi bakteri.

Jenis leukosit pada ikan gurami terdiri atas limfosit, monosit, neutrofil namun jarang ditemukan basofil dan eusinofil sebagaimana yang diungkapkan oleh Mulyani (2006). Rataan persentase limfosit minggu ke-1, ke-2, dan ke-3 dari masing-masing perlakuan berkisar antara 93\%-96\% (Gambar 3).

Rataan persentase limfosit pada perlakuan berbagai sediaan vaksin M. fortuitum pada darah ikan gurami pada minggu ke-1, ke-2 maupun ke-3 pascavaksinasi mengalami fluktuasi. Jumlah limfosit pada ikan lebih banyak daripada neutrofil maupun mono-

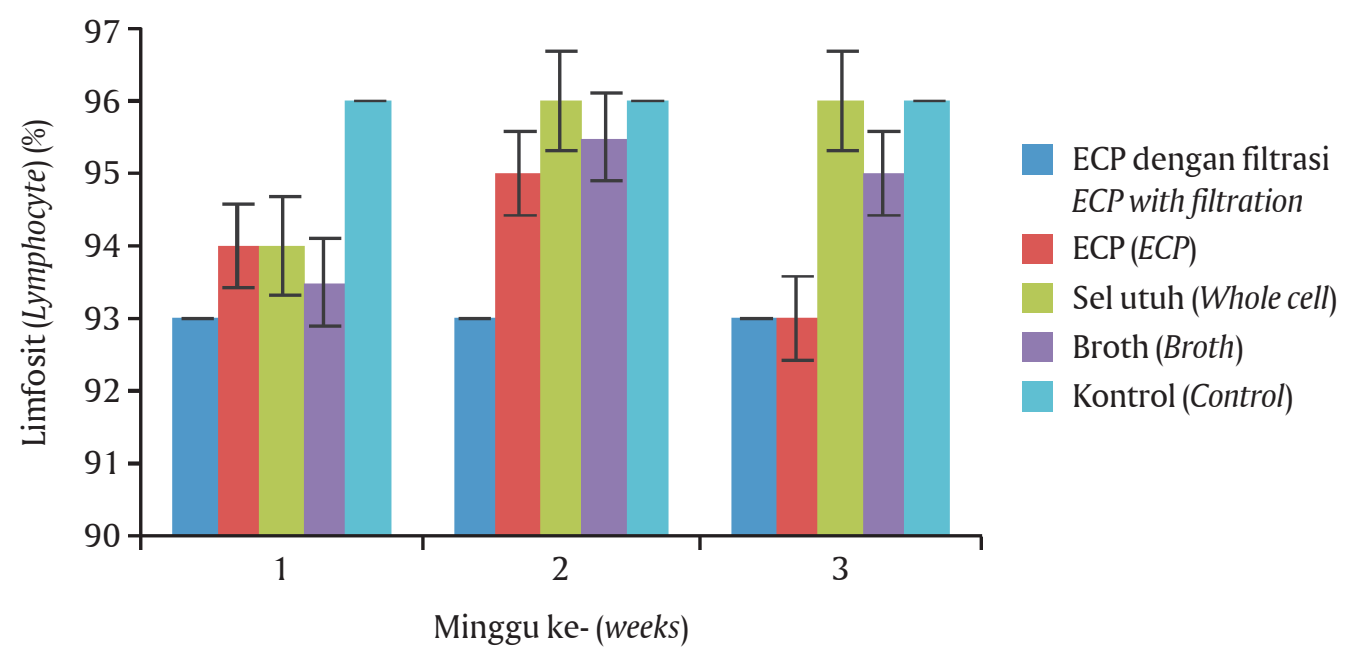

Gambar 3. Persentase total limfosit sel darah putih ikan gurami pascavaksinasi dengan berbagai sediaan vaksin $M$. fortuitum

Figure 3. Totally percentage of lymphocyte in white blood cell gouramy post vaccination by many kinds of $M$. fortuitum vaccine 
sit karena limfosit merupakan penghasil antibodi untuk kekebalan tubuh. Produksi antibodi adalah suatu proses yang terjadi dalam limfosit sebagai reaksi terhadap kehadiran bahan protein asing (antigen), termasuk sel-sel bakteri.

Persentase jumlah monosit pada perlakuan vaksin pascavaksinasi minggu ke-1 hingga ke-3 terlihat fluktuatif (Gambar 4), yaitu meningkat pada minggu ke-1 pascavaksinasi, menurun pada minggu ke-2 dan kembali meningkat pada minggu ke-3. Peningkatan jumlah monosit pada perlakuan vaksin merupakan kondisi respons imun yang alamiah terhadap antigen yang akan dikenali tubuh sebagai benda asing. Monosit berfungsi sebagai fagosit terhadap benda asing yang masuk ke dalam tubuh. Monosit akan bergerak ke arah luka untuk melakukan fagositosis. Masa hidup monosit sangat cepat hanya berkisar 10-20 jam setelah diproduksi (Guyton \& Hal, 1997).

Persentase jumlah neutrofil mengalami fluktuasi, terjadi peningkatan pada minggu ke-2 dan ke-3 pascavaksinasi (Gambar 5). Peningkatan jumlah neutrofil yang terlihat pada perlakuan berbagai sediaan vak$\sin M$. fortuitum mengindikasikan bahwa vaksin bekerja menginduksi sistem imun tubuh ikan.

Neutrofil merupakan komponen darah putih yang pertama kali akan meninggalkan pembuluh darah dan berkomplemen dengan lisosom (vakuola berisi enzim) yang akan digunakan sel untuk menghancur-

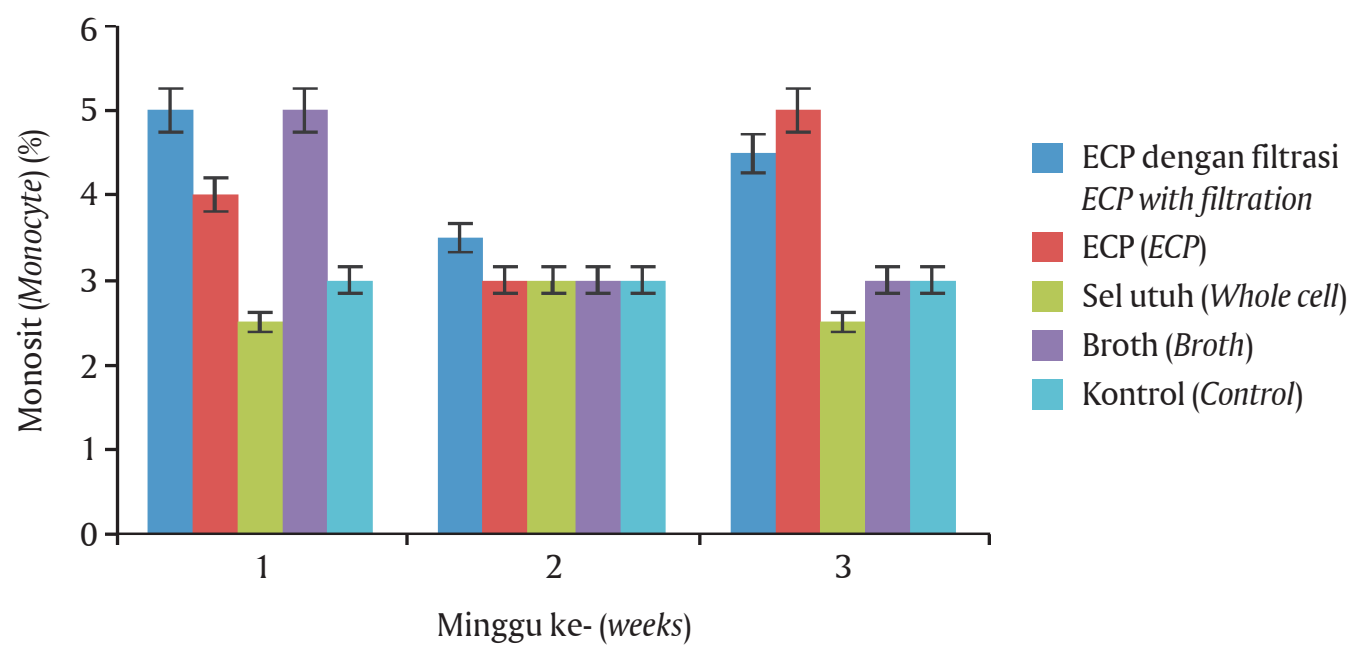

Gambar 4. Persentase total monosit sel darah putih ikan gurami pascavaksinasi dengan berbagai sediaan vaksin $M$. fortuitum

Figure 4. Totally percentage of monocyte in white blood cell gouramy post vaccination by many kinds of $M$. fortuitum vaccine

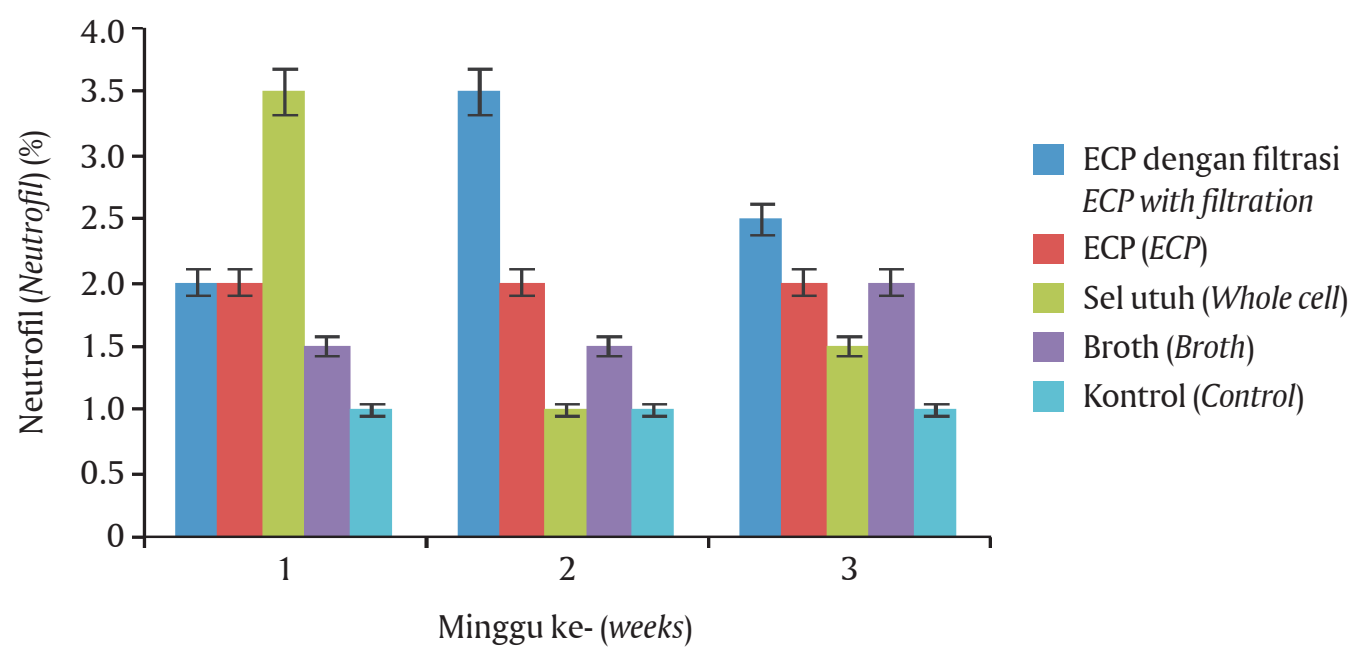

Gambar 5. Persentase total neutrofil sel darah putih ikan gurami pascavaksinasi dengan berbagai sediaan vaksin $M$. fortuitum

Figure 5. Totally percentage of neutrofil in white blood cell gouramy post vaccination with different vaccine preparation of $M$. fortuitum vaccine 
kan benda asing. Menurut Ellis et al. (1978), neutrofil pada ikan sama seperti pada mamalia tetapi memiliki proporsi yang cenderung lebih sedikit yaitu 6\%-8\%. Rendahnya persentase neutrofil pada minggu ke-2 dibanding jenis sel darah putih yang lain dikarenakan umumnya neutrofil ditemukan dan terakumulasi di daerah infeksi, mengingat neutrofil bergerak aktif menuju daerah infeksi pada saat terjadinya luka.

Aktivitas fagositosis diukur dari nilai persentase fagositosis dan indeks fagosit. Hasil penelitian menunjukkan peningkatan persentase fagositosis setelah satu minggu pascavaksinasi, selanjutnya menurun setelah dua minggu pascavaksinasi dan kembali meningkat setelah tiga minggu pascavaksinasi (Gambar
6). Nilai persentase fagositosis pada perlakuan vaksin menunjukkan persentase yang lebih tinggi dibanding kontrol $(\mathrm{P}<0,05)$.

Indeks fagositik ikan gurami pascavaksinasi dengan berbagai sediaan vaksin $M$. fortuitum menunjukkan penurunan pada minggu ke-2 dan meningkat kembali pada minggu ke-3, dapat dilihat pada Gambar 7. Hasil analisis indeks fagosit dari perlakuan vaksin monovalen dan bivalen berbeda nyata $(\mathrm{P}<0,05)$ dibanding dengan kontrol.

Aktivitas fagositosis dari perlakuan berbagai sediaan vaksin $M$. fortuitum menunjukkan perbedaan nyata $(\mathrm{P}<0,05)$ terhadap kontrol, hal tersebut menunjukkan bahwa pemberian vaksin mampu mening-

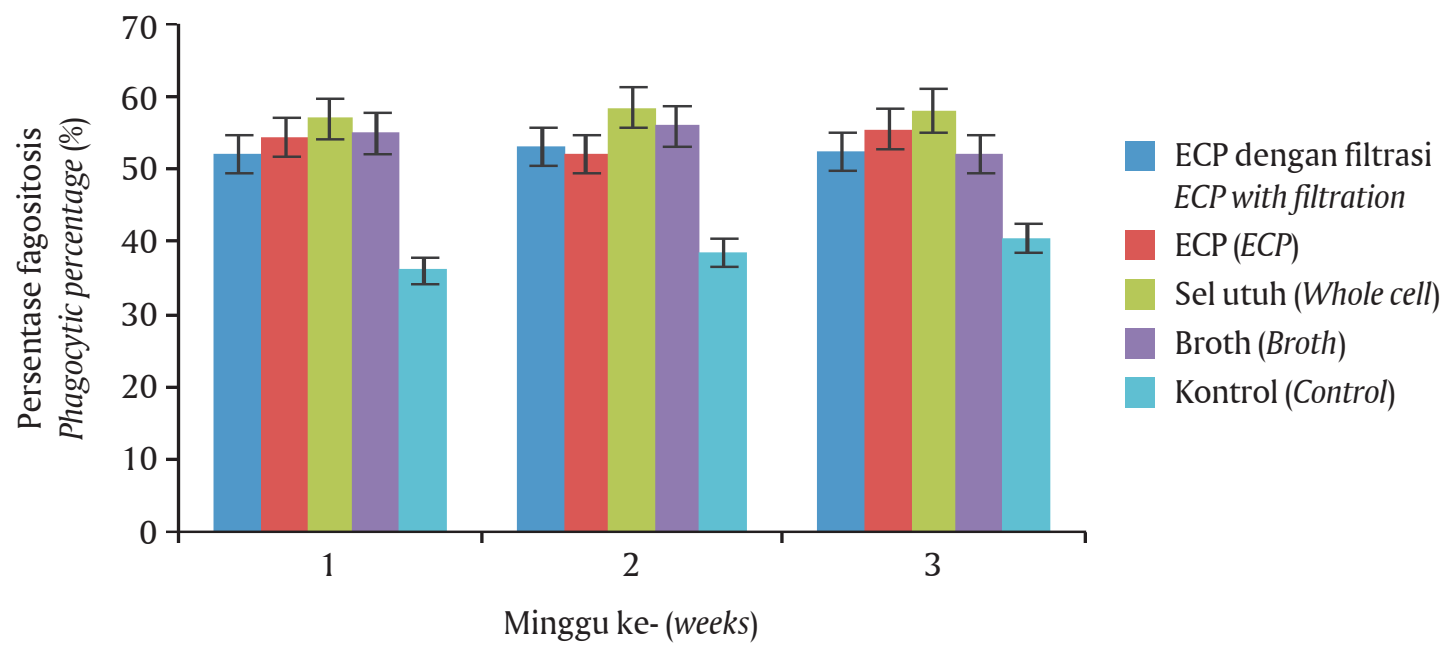

Gambar 6. Persentase fagositosis ikan gurami pascavaksinasi dengan berbagai sediaan vaksin M. fortuitum

Figure 6. Phagocytic percentage of gouramy post-vaccination with different vaccine preparations of M. fortuitum

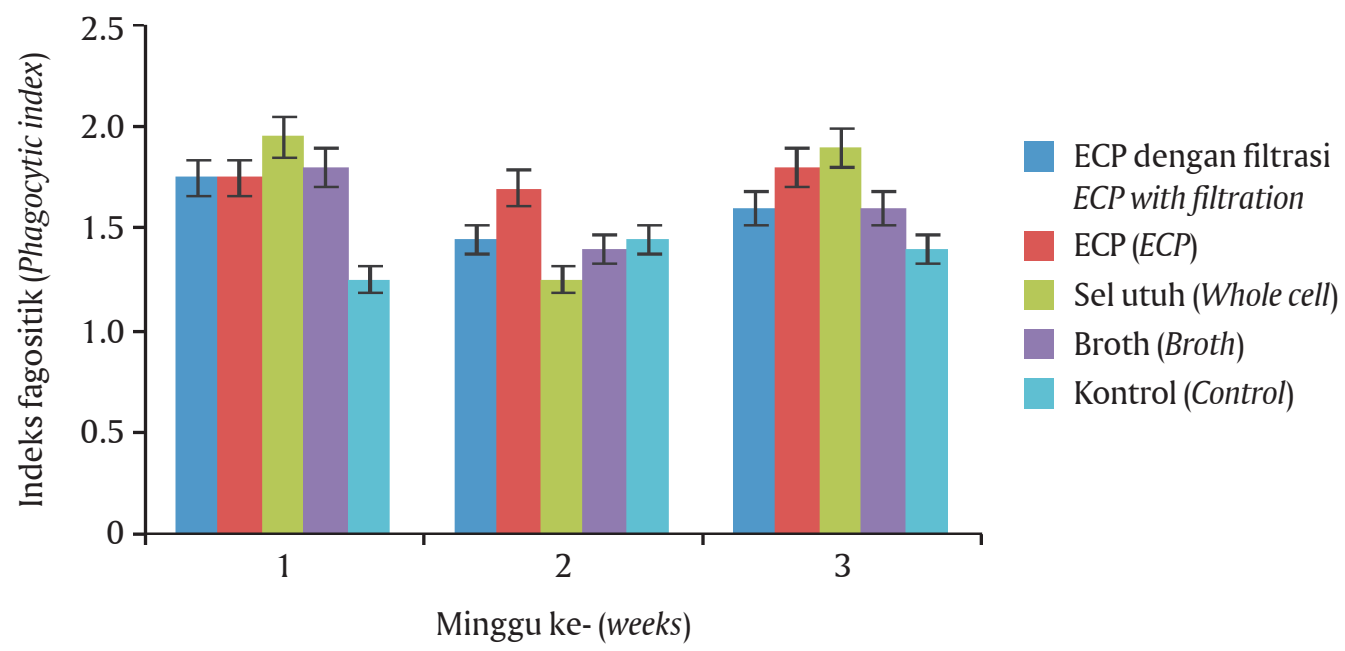

Gambar 7. Indeks fagositik ikan gurami pascavaksinasi dengan berbagai sediaan vaksin M. fortuitum

Figure 7. Phagocytic index of gouramy post vaccination with different vaccine preparation of M. fortuitum 
katkan kemampuan bakterisidal serum ikan terhadap invasi antigen vaksin. Fagositosis adalah proses seluler dari fagosit dan protista yang menggulung partikel padat dengan membran sel dan membentuk fagosom internal. Fagositosis adalah bentuk spesifik dari endositosis yang melibatkan internalisasi vesikular terhadap partikel padat, seperti bakteri, dan bentuk lain yang cukup berbeda dengan fagositosis, yaitu pinositosis, yaitu internalisasi vesikular terhadap berbagai cairan. Fagositosis bertanggung jawab terhadap akuisisi nutrisi pada beberapa sel, dan di dalam sistem imunitas, fagositosis adalah mekanisme utama untuk menghilangkan patogen dan serpihan sel. Bakteri, sel mati jaringan, dan partikel mineral kecil adalah contoh objek yang akan difagositasi.

Vaksin yang diberikan merupakan komponen bakteri yang telah diinaktifasi dan masuk ke dalam aliran darah akan dikenali sebagai antigen yang akan merangsang respons imun spesifik dan apabila terpapar dalam jangka lama akan membentuk suatu memori. Menurut Skinner et al. (2010), bahwa respons imun non spesifik akan mengalami fluktuasi sesaat setelah invasi antigen dalam hitungan hari, sedangkan respons imun spesifik terbentuk dalam hitungan minggu. Kedua respons imun tersebut berperan penting dalam mekanisme tanggap kebal ikan terhadap serangan patogen. Sugiani (2012) menyatakan bahwa aktivitas fagositosis dapat terjadi apabila ada reaktif oksigen yang bekerja sendiri maupun bersama-sama dengan enzim lisosim dalam membunuh bakteri sebagai sel asing.

Kematian ikan akibat infeksi bakteri M. fortuitum mulai terjadi pada hari ke-18 sampai hari ke-28 (Gambar 8 ). Kematian ikan akibat infeksi $M$. fortuitum ter- tinggi terjadi pada perlakuan vaksin $M$. fortuitum sediaan ECP dengan filtrasi. Pola infeksi akibat infeksi $M$. fortuitum menyebabkan infeksi yang bersifat kronis. Berdasarkan analisis sidik ragam menunjukkan bahwa perlakuan berbagai sediaan vaksin $M$. fortuitum berbeda nyata $(\mathrm{P}<0,05)$ dengan kontrol setelah diuji tantang.

Pada perlakuan vaksin ECP dengan fitrasi menunjukkan kematian tertinggi pada hari ke-19 sedangkan pada perlakuan vaksin lain secara signifikan terjadi pada hari ke-25. Perlakuan vaksin sel utuh menunjukkan jumlah kematian yang relatif lebih rendah dari perlakuan vaksin lain dan berbeda nyata $(P<0,05)$ dari kontrol, hal tersebut menunjukkan tingkat proteksi yang lebih baik terhadap infeksi bakteri $M$. fortuitum.

Parameter respons imun spesifik dan non spesifik yaitu: titer antibodi, diferensial leukosit, dan aktivitas fagositosis pada perlakuan vaksin setelah uji tantang dengan bakteri $M$. fortuitum menunjukkan hasil yang berbeda nyata $(\mathrm{P}<0,05)$ terhadap kontrol dapat dilihat pada Tabel 2 .

Kemampuan fagositosis pada ikan gurami yang divaksin dengan berbagai sediaan vaksin M. fortuitum setelah diuji tantang dengan bakteri M. fortuitum menunjukkan berbeda nyata $(\mathrm{P}<0,05)$ dibandingkan kontrol. Aktivitas fagositosis yang tinggi mengindikasikan vaksin mampu meningkatkan komponen respons imun non spesifik pada ikan sehingga mampu menghancurkan bakteri yang masuk sebagai benda asing ke dalam tubuh ikan.

Respons imun spesifik ikan diekspresikan dengan adanya aglutinasi terhadap antigen dan presipitasi

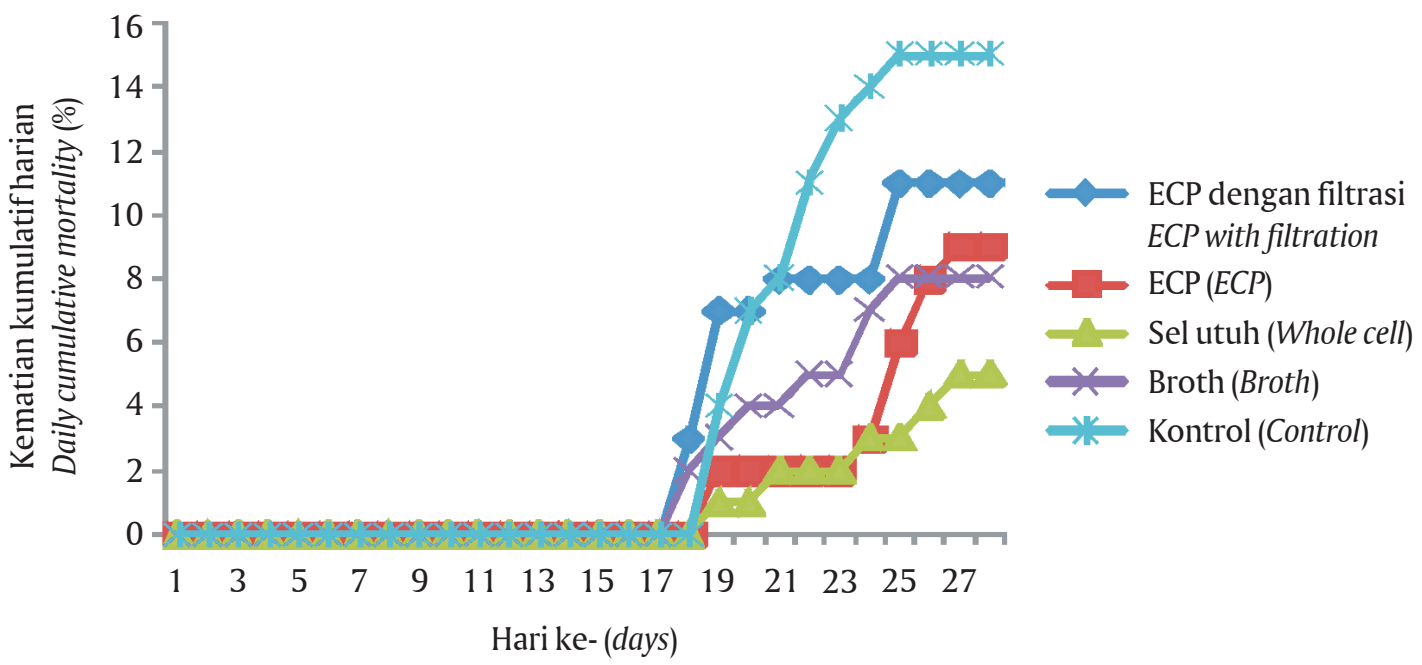

Gambar 8. Kematian kumulatif harian ikan gurami yang divaksinasi dengan berbagai sediaan vaksin $M$. fortuitum setelah diuji tantang dengan bakteri $M$. fortuitum

Figure 8. Daily cumulative mortality of gouramy vaccinated with different vaccine preparation of M. fortuitum after challenge with M. fortuitum 
Tabel 2. Parameter respons imun efikasi berbagai sediaan vaksin setelah diuji tantang dengan M. fortuitum

Table 2. Hematologic and immune response of efficacy different vaccine preparations of $\mathbf{M}$. fortuitum after challenge with bacteria $M$. fortuitum

\begin{tabular}{lcccccc}
\hline \multirow{2}{*}{$\begin{array}{c}\text { Perlakuan } \\
\text { Treatments }\end{array}$} & IP & PP & $\begin{array}{c}\text { Ab } \\
\text { (log2) }\end{array}$ & & \multicolumn{3}{c}{$\begin{array}{c}\text { Diferensial leukosit } \\
\text { Differential leucocyte (\%) }\end{array}$} \\
\cline { 6 - 8 } & & & & $\mathbf{L}$ & $\mathbf{M}$ & $\mathbf{N}$ \\
\hline Vaksin ECP dengan fitrasi & $1.95 \pm 0.05$ & $61.5 \pm 2.5$ & 4 & $85.5 \pm 1.00$ & $4.5 \pm 2.5$ & $10 \pm 3$ \\
ECP with filtration vaccine & $2.1 \pm 0.3$ & $62.5 \pm 3.5$ & 4 & $85 \pm 4$ & $5.5 \pm 4.5$ & $9.5 \pm 0.5$ \\
Vaksin ECP (ECP vaccine) & $2.85 \pm 0.15$ & $70 \pm 2.0$ & 7 & $87.5 \pm 3.5$ & $8 \pm 1.5$ & $4.5 \pm 0.5$ \\
Vaksin sel utuh (Whole cell vaccine) & $2.65 \pm 0.05$ & $67 \pm 3.0$ & 5 & $86 \pm 1$ & $9 \pm 1$ & $5 \pm 0$ \\
Vaksin broth (Broth vaccine) & $1.3 \pm 0.1$ & $48.5 \pm 7.5$ & 1 & $81 \pm 2$ & $4.5 \pm 0.5$ & $14.5 \pm 2.5$ \\
Kontrol (Control) & & & & & & \\
\hline
\end{tabular}

Keterangan (Note):

$\mathrm{IP}=$ Indek fagositik (Phagocytic index), $\mathrm{PP}=$ Persentase fagosit (Phagocytic percentage), $\mathrm{Ab}=$ Antibodi $($ Antibody), $\mathrm{L}=\mathrm{Limfosit}$ (Limphocyte), $\mathrm{M}=$ Monosit (Monocyte), $\mathrm{N}=$ Neutrofil (Neutrofil)

terhadap antigen terlarut (Nitimulyo \& Triyanto, 1990). Pemberian vaksin pada ikan menstimulasi terbentuknya antibodi dalam jumlah banyak yang teridentifikasi dengan terjadinya penggumpalan yang dikenal dengan titer antibodi. Titer antibodi ikan gurami yang divaksin dengan berbagai sediaan vaksin $M$. fortuitum menunjukkan nilai titer antibodi $\log 2$ yang berbeda nyata $(\mathrm{P}<0,05)$ dibandingkan dengan kontrol setelah ditantang dengan bakteri $M$. fortuitum. Pada perlakuan vaksin sediaan sel utuh menunjukkan nilai titer yang lebih tinggi daripada sediaan vaksin lain dan kontrol setelah ditantang. Imunoglobulin pada ikan hanya menyerupai IgM (IgM like) sehingga pembentukan antibodi pascavaksinasi pada ikan tidak seoptimal pada hewan tingkat tinggi.

Persentase total limfosit pada perlakuan berbagai sediaan vaksin pasca uji tantang dengan bakteri M. fortuitum menunjukkan nilai yang berbeda nyata $(\mathrm{P}<0,05)$ dengan kontrol. Hal tersebut menandakan bahwa pemberian berbagai sediaan vaksin dapat meningkatkan jumlah limfosit untuk menghasilkan antibodi. Proporsi komponen sel darah putih yaitu: limfosit, monosit dan neutrofil merupakan indikator respons imun non spesifik. Limfosit tidak bersifat fagositik namun memegang peranan penting dalam pembentukan antibodi. Kekurangan jumlah limfosit dapat menurunkan konsentrasi antibodi dan menyebabkan meningkatnya serangan penyakit.

Neutrofil berperan pada aktivitas fagositik dan sitotoksik, bermigrasi ke tempat inflamasi dan infeksi atas pengaruh faktor kemotaktik. Peran utama neutrofil adalah sebagai pertahanan awal imun non spesifik terhadap infeksi bakteri. M. fortuitum merupakan tipe bakteri yang menghasilkan produk ekstraselular, di mana toksin yang dihasilkan akan di- netralkan dan bakteri yang masuk akan dieliminasi oleh sel fagosit yaitu: neutrofil, monosit dan makrofag. Dinding bakteri M. fortuitum mengandung suatu komponen lipid yang dapat menghambat penggabungan fagosom dengan lisosom sehingga menyebabkan respons imun terhadap infeksi dan pembentukan respons imun spesifik yang diperantarai sel-sel limfosit juga menjadi terhambat. Perbedaan dalam dinding sel strain mikobakteri bisa menjadi alasan untuk memicu sitokin yang berbeda terhadap respons inflamasi yang berbeda. Beberapa sitokin (seperti interleuken-4, IL-4 dan interferon-g, IFN-g) menginduksi pembentukan sel raksasa dari monosit darah/ makrofag. Dengan bantuan ofeither IL-3 atau granulosit-makrofag colony-stimulating factor (GM-CSF), IL-4 menginduksi sel raksasa yang sangat besar sampai dengan 285 inti, sedangkan IFN-g cenderung menginduksi sel yang relatif kecil raksasa (misalnya 16 inti per sel) (Talaat et al., 1999).

Tingkat sintasan (\% SR) ikan pada perlakuan vaksin berbeda nyata $(\mathrm{P}<0,05)$ dari kontrol, hal tersebut dapat dilihat pada Tabel 3. Tingkat sintasan pada perlakuan vaksin sediaan sel utuh menunjukkan tingkat sintasan tertinggi sebesar $83,33 \%$ dibanding sediaan vaksin lain dan kontrol.

Nilai RPS perlakuan berbagai sediaan vaksin $M$. fortuitum setelah diuji tantang dengan bakteri $M$. fortuitum terlihat pada Tabel 4. Vaksin sediaan sel utuh menunjukkan nilai RPS sebesar $66,67 \%$ berbeda nyata dengan perlakuan vaksin lain $(\mathrm{P}<0,05)$ setelah uji tantang dengan bakteri $M$. fortuitum. Vaksin sediaan ECP dengan fitrasi menunjukkan nilai RPS terendah yaitu sebesar $26,67 \%$ berbeda nyata $(P<0,05)$ dari perlakuan vaksin lain setelah ditantang dengan M. fortuitum. 
Tabel 3. Tingkat sintasan ikan yang divaksinasi dengan berbagai sediaan vaksin M. fortuitum Table 3. Survival rate (SR) of gouramy vaccinated with different vaccine preparation of M. fortuitum

\begin{tabular}{lc}
\hline \multicolumn{1}{c}{ Perlakuan (Treatments) } & $\begin{array}{c}\text { Tingkat sintasan } \\
\text { Survival rate (\%) }\end{array}$ \\
\hline Vaksin ECP dengan fitrasi (ECP with filtration vaccine) & $63.33^{\mathrm{b}}$ \\
Vaksin ECP (ECP vaccine) & $70^{\mathrm{b}}$ \\
Vaksin sel utuh (Whole cell vaccine) & $83.33^{\mathrm{a}}$ \\
Vaksin broth (Broth vaccine) & $73.33^{\mathrm{b}}$ \\
Kontrol (Control) & $50^{\mathrm{c}}$ \\
\hline
\end{tabular}

Keterangan (Note):

Angka yang diikuti oleh huruf yang sama pada kolom yang sama menunjukkan tidak berbeda nyata pada taraf uji $\mathrm{P}>0,05$ (The same alphabet on the same rows means not significantly different $(P>0.05)$ )

Tabel 4. Tingkat RPS ikan gurami yang divaksinasi dengan berbagai sediaan vaksin M. fortuitum setelah ditantang dengan bakteri M. fortuitum

Table 4. Relative Percent Survival (RPS) levels of gouramy vaccinated with different vaccine preparation of $M$. fortuitum

\begin{tabular}{lc}
\hline \multicolumn{1}{c}{ Perlakuan (Treatments ) } & Relative Percent Survival (RPS) \\
\hline Vaksin ECP dengan fitrasi (ECP with filtration vaccine) & $26.67^{\mathrm{c}}$ \\
Vaksin ECP (ECP vaccine) & $40^{\mathrm{b}}$ \\
Vaksin sel utuh (Whole cell vaccine) & $66.67^{\mathrm{a}}$ \\
Vaksin broth (Broth vaccine) & $46.33^{\mathrm{b}}$ \\
\hline
\end{tabular}

Keterangan (Note):

Angka yang diikuti oleh huruf yang sama pada kolom yang sama menunjukkan tidak berbeda nyata pada taraf uji $\mathrm{P}>0,05$ (The same alphabet on the same rows means not significantly different $(P>0.05)$ )

Tingkat sintasan perlakuan vaksin sel utuh sebesar $83,33 \%$ dan lebih tinggi dari perlakuan vaksin lain. Berdasarkan nilai RPS maka sediaan sel utuh mampu merangsang respons imun spesifik dan non spesifik pada ikan gurami serta efektif memberikan level proteksi yang lebih baik dari sediaan vaksin $M$. fortuitum lain, hal ini sesuai dengan pernyataan Ellis (1988) bahwa vaksin dikatakan efektif jika memiliki nilai sintasan relatif (\% RPS) 8 50\%. Pemaparan antigen dalam tubuh ikan dalam dosis yang tepat dapat merangsang imunitas secara optimal \& efektif.

\section{KESIMPULAN}

Vaksin M. fortuitum sediaan sel utuh menunjukkan hasil terbaik untuk mencegah penyakit Mycobacteriosis dengan nilai tingkat sintasan sebesar 83,33\% dan nilai sintasan relatif sebesar $66,67 \%$.

\section{UCAPAN TERIMA KASIH}

Penulis mengucapkan terima kasih kepada rekan teknisi yaitu: Edy Farid Wadjdy, Ahmad Wahyudi, Bambang Priadi, dan Mikdarullah atas bantuannya selama pelaksanaan penelitian ini.

\section{DAFTAR ACUAN}

Anderson, D.P., Capstiek, P.B., \& Mowat, G.N. (1970). In vitro method for safety of FMD. J. hyg. Gamd., 68, 159-172.

Anderson, D.P., \& Siwicki, A.K. (1995). Basic hematology and serology for fish health programs. In: Shariff, M., Arthur, J.R., Subasinghe, R.P., editor. Fish Health Section. Asia Fisheries Society (eds.), Disease in Asian Aquaculture II. Manila, Philippines, p. 185-202.

Bangkit, I. (2011). Efektivitas vaksin Mycobacterium fortuitum yang diinaktivasi dengan formalin untuk pencegahan Mycobacteriosis pada ikan gurami (Osphronemus gouramy). Skripsi. Jurusan Perikanan Fakultas Perikanan dan Ilmu Kelautan. Universitas Padjadjaran. Jatinangor, $58 \mathrm{hlm}$.

Chen, S.C., Adams, A., \& Richards, R.H. (1997). Extracellular products from Mycobacterium spp. in fish. Journal of Fish Diseases, 20, 19-25.

Ellis, A.E., Roberts, R.J., \& Tytler, P. (1978). The Anatomy and Physiology of Teleosts. In: Robeets R.J. Fish Pathology. Balliere Tindall, London. 
Ellis, A.E. (1988). Fish Vaccination, Academic Press, London, 255 pp.

Encheva, V., Gharbia, S.E., Wait, R., Begum, S., \& Shah, H.N. (2006). Comparison of extraction procedures for proteome analysis of Streptococcus pneumoniae and a basic reference map. John Wiley.

Guyton, A.C., \& Hall, J.E. (1997). Buku Ajar Fisiologi Kedokteran Edisi 9. Penerbit Buku Kedokteran EGC.

Irianto, A. (2005). Patologi ikan teleostei. Gadjah Mada University Press. Yogjakarta, $256 \mathrm{hlm}$.

Jawetz, E., Melnick, L.J., \& Adelberg, A.E. (1996). Mikrobiologi Kedokteran, Edisi-20, alih bahasa Edi Nugroho, R.F. Maulany, C.V EGC, Jakarta, hlm. 236-237.

Purwaningsih, U., Lusiastuti, A.M., \& Taukhid. (2009). Studi Patologi-Anatomi Penyakit Mycobacteriosis pada ikan gurami (Osphronemus gouramy). Prosiding Forum inovasi Teknologi Akuakultur, hlm. 1139-1142.

Skinner, L.A., Schulte, P.M., Balfry, S.K., McKinley, R. S., \& LaPatra, S.E. (2010). The association between metabolic rate, immune parameters, and growth performance of rainbow trout, Oncorhynchus my- kiss (Walbaum), following the injection of DNA vaccine alone and concurrently with a polyvalent, oil-adjuvanted vaccine. Fish \& Shellfish Immunology, 28: 387-393.

Stuart, M. (1999). Immunology Spring 1999. Department of Mycrobiology/Immunology. Kirkville College of Osteopathic Medicine. http:/www.kcom. cdu/faculty/chamberlain/msimn (diakses 2 Juni 2013).

Sugiani, D. (2012). Vaksin bivalen untuk pencegahan penyakit Motile Aeromonas Septicemia dan Streptococcosis pada ikan nila (Oreochromis niloticus) [disertasi]. Bogor. Sekolah Pascasarjana Institut Pertanian Bogor.

Talaat, A.M., Trucksis, M., Kane, A.S., \& Reimshuessel, R. (1999). Pathogenicity of Mycobacterium fortuitum and Mycobacterium smegmatis to goldfish, Carrasius auratus. Journal of Veterinary Microbiology, 66, 151-164.

Zhang, J., Zou, W., \& Yan, Q. (2008). Non-specific immune response of Bullfrog Rana catesbeiana to intraperitoneal injection of bacterium Aeromonas hydrophila. Chinesse Journal of Oceanology and Limnology, 26(3), 248-255. 